\title{
ANTITRUST IMMUNITIES OF COOPERATIVE ASSOCIATIONS
}

\author{
JoHn HANNA*
}

Cooperative associations other than agricultural are subject to the same rules on restraint of trade as other corporations. ${ }^{1}$ Agricultural cooperatives in their normal marketing and purchasing activities have nothing to fear from state antitrust legislation. Without any exemption in federal antitrust laws, the state and federal legislative approval of farm cooperatives, expressing a widespread public confidence in the utility of cooperative enterprise, would likely have induced the courts to conclude that the slight and incidental restraints on trade by agricultural associations in their normal operations are not unreasonable. To make this certain, agricultural producers' cooperatives are granted a degree of immunity by the Clayton Act, the Capper-Volstead Act, and the Robinson-Patman Act. This immunity is not absolute, but so long as the agricultural associations conduct themselves with some sense of responsibility and refrain from conspiring with non-agricultural interests, the antitrust laws need not be of much concern to those who formulate the policies of the associations. This .conclusion could have been and was reached by most students of agricultural cooperatives during the rapid expansion from 1920 to 1930 , and requires no modification today.

Farmers expressed their sense of economic insecurity during the latter part of the nineteenth century, and later, by enthusiastically aiding in the passage of state antitrust laws and the Sherman Act. They tried, sometimes successfully, to have their own organizations exempted from the penal provisions of these statutes. Where they were unsuccessful they often found that their first feeble attempts at cooperative action were held to be illegal, while the enlargement of business units continued with only minor setbacks. ${ }^{2}$ Where they were successful the outcome in

- A.B. 1914, Dartmouth College; A.M. I915, Stanford University; LL.B. I918, Harvard University. Professor of Law, Columbia University. Member of Committec on Legal Education, American Institute of Cooperation. Author, Law of Cooperattve Marketing Assoctations (1931).

${ }^{1}$ See Hanna, Co-Operative Associations and the Public, 29 Mrct. L. Rev. 148 (1930); Cooperative Milk Marketing and Restraint of Trade, 23 KY. L. J. 217 (I935). See also Nourse, THE LEgat Status op AGriculturaI CO-ORERATION 216-217, 334-423 (1927).

'In Reeves v. Decorah" Farmers' Co-operative Society, I60 Iowa 194, I40 N.W. 844 (1913), a provision that a member of a hog growers' association should ship all hogs through the association or pay five cents a bundredweight on hogs shipped otherwise was held in restraint of trade as to an independent buyer. Apparently the Iowa court thought that any cooperative contract which adversely affected an existing middleman was illegal.

The Illinois Supreme Court in Ford v. Chicago Milk Shippers' Association, 155 Ill. I66, 39 N. E. $65 I$ (I895), held a milk producers' cooperative violated a state antitrust law merely because the $r, 500$ members agreed to market all their milk through their association.

See also Burns v. Wray Farmers' Grain Co., 65 Colo. 425, 176 Pac. 487 (1918). 
several instances was the invalidation of the entire state antitrust law as a violation of the equal protection clause of the Fourteenth Amendment. ${ }^{3}$

Following World War I there was a notable development of agricultural cooperatives, especially marketing associations. Most of the states passed new cooperative statutes having a high degree of similarity. These statutes generally contained sections exempting agricultural cooperatives from the application of the state antitrust laws, so long at least as the cooperatives merely carried on the activities authorized by statute. The Federal Government through the War Finance Corporation and other agencies actively assisted agricultural associations by advice and financial assistance. The state courts recognized the overwhelming public opinion to the effect that the normal operations of cooperative associations of farmers were not in unreasonable restraint of trade. They further upheld the statutory exemption from the antitrust laws as reasonable classification. State judicial opinion was confirmed by federal judges and by the Supreme Court.4 The present judicial attitude is illustrated by the following quotations from Mr. Justice Frankfurter's opinion in Tigner v. Texas. ${ }^{5}$ Referring to antitrust legislation following the Civil War, he says:

The leading case on this point is Connolly v. Union Sewer Pipe Co., r84 U. S. 540 (I902). The Connolly case involved an Illinois antitrust law which stated: "The provisions of this act shall not apply to agricultural products or live stock while in the hands of the producer or raiser." Id. at 554. There was no simple legislative declaration that farmers' association activities were not to be regarded as in restraint of trade. The act.in question said, in effect, "certain acts are unlawful except when done by farmers." The Court, after enumerating the forbidden items of conduct which farmers could do without penalty, concluded the statute was repugnast to equal protection.

- Even as interpreted above the Connolly case apparently is no longer law. It was distinguished in Liberty Warehouse Co. v. Burley Tobacco Growers Co-op. Ass'n, 276 U. S. 7I (I928), and apparently overruled by Tigner v. Texas, 3 ro U. S. I4I (I940).

${ }^{5} 3$ Io U. S. I4I (1940). Mr. Justice Frankfurter, in delivering the opinion of the Court with but one dissent, said: "The court below recognized that the exemption was identical with that deemed fatal to the Illinois statute in Connolly's case. But it felt that time and circumstances had drained that case of vitality. ..."Id. at I44. After reviewing the Texas and other legislation and the economic situation of farmers and others, the learned Justice observed: "And so we conclude that to write into law the differences between agricultural and other economic pursuits was within the power of the Texas legislature. Connolly's case has been worn away by the erosion of time and we are of the opinion that it is no longer controlling." Id. at I47.

The changing course of decision may be seen by noting the cases cited in L. S. HuLBERT, LEgaL Phases of Cooperative Associations 207 and passim (Farm Credit Administration, U. S. Dep't of AGric., Burl. No. 50, 1942). This volume also contains an exhaustive table of cases and bibliography. See especially List v. Burley Tobacco Growers' Co-op. Ass'n, I14 Ohio 361, I5I N. E. 471 (I926); Stark Company Milk Producers Ass'n v. Tabeling, 129 Ohio 159, r94 N. E. 16 (1934); Northern Wisconsin Co-op Tobacco Pool v. Bekkedal, I82 Wis. 571, 197 N. W. 936 (1923); Liberty Warehouse Co. v. Burley Tobacco Growers' Co-op. Ass'n, 276 U. S. 71 (Ig28); Tigner v. Texas, supra note 3. Frost v. Corporation Comm'n of Oklahoma, 278 U. S. 515 (1929), indicates that the state classifications may not always be upheld as constitutional, but the case today, if authority at all, is probably of restricted application. See Hanna, supra note, $\mathrm{I}$, at 185 .

The standard cooperative marketing act of the Twenties is set out and analyzed in Jorns HaNNA, Law of Cooperative Marketing Associations (x93 ). See also Cowling, Cooperattves in America (1938); Frank Evans, The Trend of Judicial Decision in Cooperative Marketing (1925); Frank Evans and E. A. Stokdyk, The Law of Cooperative Marketing (I937); Israes Packel, The Laf op the Organization and Operation of Cooperatives (2d ed. r947).

The National Conference of Commissioners on Uniform State Laws presented in 1936 a Uniform Agricultural Cooperative Association Act, subsequently designated a model Act. This Act was drafted 
Law was invoked to buttress the traditional system of free competition, free markets and free enterprise. Pressure for this legislation came more particularly from those who as producers, as well as consumers, constituted the most dispersed economic groups. These large sections of the population-those who labored with their hands and those who worked the soil-were as a matter of economic fact in a different relation to the community from that occupied by industrial combinations. ... In these circumstances, legislators may well have thought combinations of farmers and stockmen presented no threat to the community, or, at least, the threat was of a different order from that arising through combinations of industrialists and middlemen .... .

... An impressive legislative movement bears witness to the general acceptance of the view that differences between agriculture and industry call for differentiation in the formulation of public policy. ${ }^{6}$

\section{Before discussing federal legislation designed to relieve agricultural associations} from some of the applications of the antitrust laws, a few words may be added to emphasize the statement that non-agricultural cooperative associations have little or no such state or federal legislative immunity. ${ }^{7}$ As Mr. Justice Black stated in the Associated Press case: ${ }^{8}$

by the author. Its restraint of trade section is a synthesis of state law on restraint of trade and reads as follows:

Sec. 20. Associations Are not in Restraint of Trade. (a) No association complying with the terms hereof shall be deemed to be a conspiracy, or a combination in restraint of trade, or an illegal monopoly; or be deemed to have been formed for the purpose of lessening competition or fixing prices arbitrarily, nor shall the contracts between the association and its members, or any agreements authorized in this act, be construed as an unlawful restraint of trade, or as part of a conspiracy or combination to accomplish an improper or illegal purpose or act.

(b) An association may acquire, exchange, interpret and disseminate to its members, to other cooperative associations, and otherwise, past, present and prospective, crop, market, statistical, economic and other similar information relating to the business of the association, either directly or through an agent created or selected by it or by other associations acting in conjunction with it.

(c) An association may advise its members in respect to the current and prospective production of agricultural commodities and its relation to the prospective volumes of consumption, selling prices and existing or potential surplus, to the end that every market may be served from the most convenient productive areas under a program of orderly marketing that will assure adequate supplies without undue enhancement of prices or the accumulation of any undue surplus.

- Tigner v. Texas, supra note 5 , at $145,146$.

'A review of the studies made by the Cooperative Project on Cooperative Legislation, with particular reference to consumer cooperation, indicates that non-agricultural cooperatives have rarely been given any specal position in respect to laws on the subject of restraint of trade. Ostrolenk and Tereshtenko, Abstracts of Laws Pertaining to Cooperatives in the United States, FWA, WPA, Projects Nos. 65-1-97-21 and 465-97-3-r8. This project was subsequently a section of the Department of Labor. See Bull. No. 665. Some of the Department's later studies of cooperatives were not printed but made available in mimeographed form to certain libraries and others.

- Associated Press v. United States, 326 U. S. I (1945). The implications of this case for co. operatives will be discussed at greater length infra. The Associated Press, with some 1200 members, is a cooperative association incorporated under the Membership Corporation Law of the State of New York. Roberts, J., dissenting, id. at 48. The very history of the Associated Press further illustrates this point as Black, J., declared: "AP originally functioned as an Illinois corporation, and at that time an existing member of the Association had an absolute veto power over the application of a publisher who was or would be in competition with the old member. The Supreme Court of Illinois held that AP thus operated was in restraint of trade. Inter-Ocean Publishing Co. v. Associated Press, 184 Ill. 438, 56 N. E. $822(1900)$. As a result of this decision, the present Association was organized in New Iock." Id. at Io. See also American Medical Association v. United States, 317 U. S. 519 (1943). Cf. Lewin, The Associated Press Decision, I3 U. of Ckr. L. Rev. 247 (1946); Ellis, $A$ Reply, id. at 471. 
Victory of a member of such a combination over its business rivals achieved by such collective means cannot consistently with the Sherman Act or with practical, everyday knowledge be attributed to individual "enterprise and sagacity"; ... . [it] can only be ... the collective power of an unlawful combination. ... It is significant that when Congress has desired to permit cooperatives to interfere with the competitive system of business, it has done so expressly by legislation. ${ }^{9}$

This is not to say that by their nature, size, and operations most consumers' and other cooperative corporations may not carry on their activities with little fear of being called to account for unlawful interference with competition.

Numerous federal statutes are relevant in considering the applicability to agricultural cooperatives of United States statutes on the subject of restraint of trade. In the first category are the antitrust acts themselves; in the second are acts indicating federal approval of the activities of such associations. The first group includes the Clayton Act, ${ }^{10}$ the Capper-Volstead Act, ${ }^{11}$ the Robinson-Patman Act, ${ }^{12}$ and various acts in which incidental reference is made to antitrust laws, such as the Agricultural Marketing Agreement Act ${ }^{13}$ and the Bituminous Coal Act. ${ }^{14}$ The Appropriations Acts for the Department of Justice from 1914 to $1928^{15}$ contained the following provision:

... no part of this appropriation shall be expended for the prosecution of producers of farm products and associations of farmers wha cooperate and organize in an effort to and for the purpose to obtain and maintain a fair and reasonable price for their products.

A partial list of federal statutes indicating government support of farm cooperative associations includes: the War Finance Corporation Act of $1918,{ }^{10}$ the Federal Intermediate Credit Bank Act of $1923,{ }^{17}$ the Agricultural Marketing Act of $1929,{ }^{18}$

- Associated Press v. United States, supra note 8, at 15, 14.

I0 38 STAT. 730 (19r4), as amended, I5 U.S.C. \$\$12-27 (1940).

2242 STAT. 388 (1922), 7 U.S.C. \$\$29I-292 (1940).

1249 STAT. 1526 (1936), 15 U.S.C. $5513-13 \mathrm{C}$ (1940)

${ }^{23} 50$ STAT. 248 (r937), 7 U.S.C. $\$ \$ 67 \mathrm{r}-674$ (r940). The Agricultural Adjustment Act of 1933 (\$8(2) ) 48 STAT. 34, referring to agreements by the Secretary of Agriculture with cooperative associations, among others, provides: "The making of any such agreement shall not be held to be in violation of any of the antitrust laws of the United States." While this Act was declared unconstitutional for reasons having nothing to do with the foregoing provision, United States v. Butler, 297 U. S. I (1935), the policy of the original Act was coptinued in the Agricultural Marketing Agreement Act of r937: "The Secretary, in the administration of [this chapter] shall accord such recognition and encouragement to producer-owned and producer-controlled cooperative associations as will be in harmony with the policy toward cooperative associations set forth in existing Acts of Congress and as will tend to promote efficient methods of marketing and distribution." 49 STat. 767 (I935), 50 SтAт. 246 (I937), 7 U.S.C. $\$ 6 \mathrm{ro}(\mathrm{b})$ ( I) (1940).

The discriminatory sections of the Agricultural Marketing Agreement Act exempting producers' cooperatives from the requirement of paying uniform prices were upheld in United States v. Rock Royal Cooperative, Inc., 307 U. S. 533 (r939).

${ }^{26}$ The Bituminous Coal Act of 1935 contained exculpating clauses relating to sale to or through farmers' cooperatives. When the Act was declared unconstitutional, Carter v. Carter Coal Co., 298 U. S. 235 (r936), it was reenacted with the same clauses mentioned above. 50 STAT. 82 (I937), I5. U.S.C. $\$ 833$ (i) (1940).

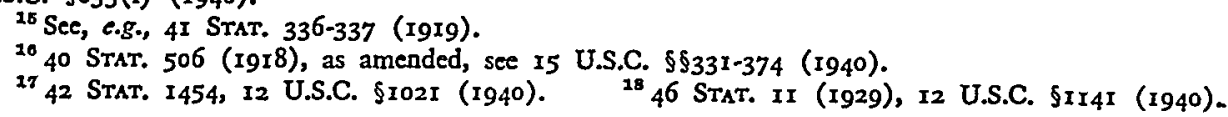


the Farm Credit Act of 1933 authorizing the banks for cooperatives, ${ }^{10}$ the Rural Electrification Act of $1936,{ }^{20}$ the Packers and Stockyards Act of $1921,{ }^{21}$ the Grain Futures Act of $1922,{ }^{22}$ the Commodity Exchange Act of $1936,{ }^{23}$ the Cooperative Marketing Act of $\mathrm{rg}_{26^{24}}$ providing for research and advisory services for cooperatives by the Department of Agriculture, and the tax-exemption provisions of various revenue acts. $^{25}$

The Sherman Anti-Trust Act of $1890^{28}$ prohibited "every . . . combination . . . in restraint of trade or commerce." The question whether the 1890 Congress which passed the law intended it to apply to labor unions or producer organizations is now outside the realm of useful inquiry. The Clayton Act was passed in rgr4 to supplement the Sherman Act. When the Clayton Act was under consideration, an alternate amendment was offered in the following language:

Provided, That this Act shall not be construed to apply to any arrangements, agreements or combinations between laborers made with a view of lessening the number of hours of their labor or the increasing of their wages; nor to any arrangements, agreements, or combinations among persons engaged in horticulture or agriculture made with a view of enhancing the price of [their own] agricultural or horticultural products. ${ }^{27}$

The amendment was defeated.28 An amendment to include an exemption of consumer organizations was also rejected. ${ }^{29}$ Congress included in Section 6 of the Clayton Act the famous sentence, "That the labor of a human being is not a commodity or article of commerce."30 Since the interpretation of the labor clauses of this section have some bearing upon the meaning of the cooperative clauses, before seeing how Section 6 and subsequent legislation have been understood in the matter of the competitive privileges of agricultural associations it may be worth while to digress for a few observations on the application of the section to labor-union practices. $^{81}$

${ }^{10} 48$ STAT. $257,26 \mathrm{r}, 12$ U.S.C. $\$ 5 \mathrm{rr34}, 1134(f)$ (1940).

${ }^{20} 49$ StAT. 1363 (1936), 7 U.S.C. \$90I (1940).

3242 STAT. 159, 7 U.S.C. \$181 (1940).

32 I2 STAT. 998, 1001. See Board of Trade v. Olsen, 262 U. S. I (1922).

2849 STAT. I49I (1936), 7 U.S.C. \$I (1940).

26 STAT. 802, 7 U.S.C. 545I (1940).

${ }^{25}$ For the present law see Internal Revenue Code $\$ 101(12)$. The law has remained about the same since 1926. See also Paul, The Justifiability of the Policy of Exempting Farmers Marketing and Purchasers Cooperative Organizations from Federal Income Taxes, 29 MinN. L. Rev. 343 (1945).

${ }^{28}$ Sherman Act, 26 STAT. 209 (I890), I5 U.S.C. \$I (1940). Clayton Act, 38 StAT. 730, 15 U.S.C. 512 (1940). Section 6 is as follows: "That the labor of a human being is not a commodity or article of commerce. Nothing contained in the antitrust laws shall be construed to forbid the existence and operation of labor, agricultural, or horticultural organizations, instituted for the purposes of mutual help, and not having capital stock or conducted for profit, or to forbid or restrain individual members of such organizations from lawfully carrying out the legitimate objects thereof; nor shall such organizations, or the members thereof, be held or construed to be illegal combinations or conspiracies in restraint of trade, under the antitrust laws." 38 STAт. 731.

37 I CONG. REC. $954^{\circ}$ (I914).

"Ibid.

${ }^{28}$ Id. at $954 \mathrm{I}$.

${ }^{30} 38$ STAT, 73r.

81 Section 20 of the Clayton Act also restricted the authority of the Federal courts to issue injunctions in labor cases, a matter more comprehensively covered later in the Norris-LaGuardia Act, 47 STAT. 70 (1932), 29 U.S.C. 5 ror (1940). Section 20 can be interpreted to legalize, regardless of purpose, most of the usual tactical weapons of labor unions. 
Mr. Justice Stone, speaking for the Court in the Apex Hosiery case, ${ }^{32}$ a decision highly favorable to labor, said: "During that period [since rg08] Congress, although often asked to do so, has passed no act purporting to exclude labor unions wholly from the operation of the [Sherman] Act." ${ }^{33}$ That was and is the opinion of the Supreme Court as to the effect of Section 6 of the Clayton Act. ${ }^{34}$ On the other hand, it has been strenuously argued not only that judicial construction applying the Sherman Act to labor unions was erroneous but that the congressional intent in Igr4 was to exclude labor unions entirely from the purview of the act.

Joseph Kovner, in discussing the legislative history of the Clayton Act, ${ }^{35}$ quotes the chairman of the House Rules Committee, Mr. Henry, as stating: "We are now about to ... make it plain and specific, by clear-cut and direct language, that the anti-trust laws against conspiracies in trade shall not be applied to labor organizations. ..." ${ }^{\text {36 }}$ Mr. Kovner goes on to discuss the hearings, the debates in the House and Senate and the amendments that were offered and rejected, and concludes that the legislative history indicates a congressional intent to exempt labor unions from the impact of the Sherman law. He thinks the Supreme Court has in fact ignored the legislative history. Mr. Kovner is bewildered that Frankfurter and Greene, in The Labor Injunction, say, "The debates in Congress looked both ways" and, "With a legislative history like that which surrounds the Clayton Act, talk about the legislative intent as a means of construing legislation is simply repeating an empty formula." ${ }^{37}$ Mr. Kovner is aware that members of Congress might have accepted the formula of Section 6 in I9I4 because they believed the Supreme Court would interpret Section 6 as in fact it has been interpreted-namely, that labor unions are exempted "only while pursuing legitimate objects by lawful means,"38 as indeed the law states. The question is whether prior cases gave the clue to the meaning of "lawful means." Mr. Kovner certainly proves the opinions of certain sponsors of Section 6 as to its meaning. That the majorities who voted for the bill and who were aware of Supreme Court opinions in situations covered by the section necessarily accepted the view of the law's proponents is by no means so apparent. While the author seems to believe that the Supreme Court has never taken sufficient account of the legislative history, it is scarcely likely that briefs on behalf of labor organizations have not explored the subject and brought the products of research

"Apex Hosiery Co. v. Leader, 310 U. S. 469 (I940).

22Id. at 487 .

"Lawlor v. Loewe, 208 U. S. 274 (1907), 235 U. S. 522 (1915).

${ }^{25}$ Kovner, The Legislative History of Section 6 of the Clayton Act, 47 CoL. L. Rev. 749 (1947).

${ }^{20}$ I ConG. REc. 954 I ( $\mathrm{rgr}_{4}$ ), quoted in id. at 749.

"Felix Frankfurter and Nathin Greene, The Labor Injunction r39-I44 (1930), quoted in Kovner, supra note 36 , at 762 .

${ }^{18}$ See Paine Lumber Co. จ. Neal, 244 U. S. 459,483 (19r6). This statement in the actual case was in the dissenting opinion of Mr. Justice Pitney. It will not escape notice that in fact the learned Justice seems to say one ascertains whether the statute punishes an act by deciding a priori whether the act is unlawful. This view beeame law after Duplex Co. v. Deering, 254 U. S. 443 (I920). The dissenters in the Duplex case, Brandeis, Holmes, and Clarke, JJ., based their dissent on Section 20, not Section 6, of the Clayton Act. 
to the attention of the Court. At any rate, the Court has never found the legislative intent for which Mr. Kovner argues. ${ }^{38^{*}}$

The limited exemption from antitrust prosecution granted to labor unions in recent cases has resulted from reliance on the Norris-LaGuardia $\mathrm{Act}^{30}$ and an analysis of the general purposes of the antitrust laws rather than from the clauses of Section 6 of the Clayton Act.

The Apex Hosiery case ${ }^{40}$ involved a sit-down strike in its most aggravated form. A union which at the time had only eight members out of the company's 2,500 employees demanded a closed shop. When this was refused the union declared a strike, seized the plant, and held it for several weeks, during which machinery and equipment was wantonly demolished or damaged to the extent of many thousands of. dollars. About 80 per cent of the finished production was ready for shipment in interstate commerce. The union specifically refused a request for shipment of this merchandise. The plaintiff sued for triple damages under the Sherman Act. The Supreme Court, while denying that the Clayton Act absolutely exempted labor unions from the provisions of the Sherman Act, found that, while the strikers committed acts which were within reach of the commerce power, there was no conspiracy in restraint of trade within the Sherman law. The tests to be applied concern the nature of the restraints and the effect on interstate commerce. Restraints which, if peaceful, are not covered by the Act are not brought under the Act because attained by violence. The purpose of the Sherman law was to preserve free competition in business and commercial transactions and prevent conduct tending to restrict production, fix prices, or otherwise control the market. The Sherman Act was not passed to police interstate commerce. In both labor and non-labor cases, restraints condemned by the antitrust laws must be intended to have, or have, effects on the competitive conditions in the industry. The Sherman Act is concerned with the character of the prohibited restraints rather than with their effects on interstate commerce. The Court, in an opinion by Mr. Justice Stone, and with a dissent by Chief Justice Hughes concurred in by Justices McReynolds and Roberts, affirmed a Circuit Court of Appeals decision reversing a judgment for the plaintiff.

In United States v. Hutcheson ${ }^{11}$ the Supreme Court affirmed a judgment quashing an indictment under the Sherman Act. The indictment resulted from a strike and secondary boycott and sympathy strikes growing out of a jurisdictional dispute. It charged a conspiracy to restrain trade with the purpose of preventing AnheuserBusch from receiving materials in interstate commerce, of preventing another corporation from obtaining materials in interstate commerce for use in performing a contract for Anheuser-Busch, and of preventing still another corporation from

${ }^{882}$ An interesting question, not here discussed, is how far, if at all, the Supreme Court should explore legislative history, debates, and hearings, to interpret statutory language. Such procedure obviously tends to impress the Court with political considerations.

${ }^{30} 47$ STAT. 70 (1932), 29 U.S.C. 5ror (1940).

10 Apex Hosiery Co. v. Leader, 310 U. S. 469 (r940).

13 I2 U. S. 219 (I94I). 
receiving materials in like manner for the construction of a building for the Gaylord Container Corporation on premises adjacent to Anheuser-Busch.

The Supreme Court, speaking through Mr. Justice Frankfurter, held that the union actions were immune from prosecution under Section 20 of the Clayton Act, construed in the light of the congressional definition of the term "labor dispute" in the Norris-LaGuardia Act. In view of the broad definition of "labor dispute," Congress had given protection in respect of the described conduct even if directed in part against outsiders to the labor dispute. Congress had expressed a national policy by determining the bounds of a labor dispute so far as related to withdrawal of injunctions. Congress could not have taken such elaborate care to permit such conduct in respect of one statute while retaining a criminal liability for such conduct under an earlier law. While the Norris-LaGuardia Act is not a tightly drawn amendment to the Clayton Act, "The underlying aim ... was to restore the broad purpose which Congress thought it had formulated in the Clayton Act but which was frustrated, so Congress believed, by unduly restrictive judicial construction."42 Mr. Justice Stone, concurring, said it was clear that the indictment failed to charge an offense under the Sherman Law and found no occasion to consider the impact of the Norris-LaGuardia Act. The learned Justice thought the restraints on interstate commerce were only those incidental to any local strike. Mr. Justice Roberts, with whom Chief Justice Hughes agreed, thought the fact that Congress forbade the issuing of injunctions to restrain certain conduct was no indication that Congress intended to repeal provisions of the Sherman Act:

I venture to say that no court has ever undertaken so radically to legislate where Congress has refused so to do. . . . In the light of this history, to attribute to Congress an intent to repeal legislation which had a definite and well understood scope and effect for decades past, by resurrecting a rejected construction of the Clayton Act and extending a policy strictly limited by the Congress itself in the Norris-La Guardia Act, seems to me a usurpation by the courts of the function of the Congress not only novel but fraught as well with the most serious dangers to our constitutional system of division of powers. ${ }^{48}$

Whether or not the effect of the Supreme Court decisions is that claimed by Mr. Justice Roberts, the fact remains that if account is taken of Sections 6 and 20 of the Clayton Act, and of the Norris-LaGuardia Act, nothing a labor union or its members can do can be invalid under the Sherman Act so long as there is a labor dispute-that is, so long as the alleged offense comes within the matrix of the employer-employee relationship; but the labor immunity does not extend to union conduct outside such matrix, whether the union and its members are acting alone or in concert with others.

Where a fish canner asked for an injunction against a CIO union of fishermen, charging an attempt to monopolize, the Supreme Court held the injunction should have been granted, reversing the Circuit Court of Appeals, which held there was

12Id. at 235-236.

1d. at 245,246 . 
no such jurisdiction. ${ }^{14}$ The defendant union was composed chiefly of owners and lessees of fishing boats, although there were also involved a few individuals, also members, who worked for other members. None of the respondents was employed by the petitioner nor sought any such employment. The union required the petitioner not to purchase fish from non-members as a condition of getting any fish from members. The union's control of the fish supply was so extensive that the petitioner had the choice of yielding or going out of business. The actual decision of the Supreme Court, a unanimous one, was that no labor dispute was involved. The District Court had jurisdiction to consider the petition.

On the remand, the union argued that irrespective of the protection to which it was entitled under the labor statutes, it was a cooperative association of fishermen in whose behalf there has been enacted a statute similar to the Capper-Volstead Act, with the Secretary of Commerce having much the same jurisdiction under the former statute as the Secretary of Agriculture has under the latter. ${ }^{45}$ The Secretary of Commerce had taken no action in respect to the alleged monopoly. The Circuit Court of Appeals ${ }^{48}$ thought on this point that it was concluded by the Borden case, ${ }^{47}$ although, as will be noted subsequently, in that case the cooperative was charged with conspiring with others, while in the California Packers' case ${ }^{\mathbf{B}}$ the defendant's monopoly power was being realized solely by an assertion of the power of the fishermen's union. The circuit court affirmed the original judgment of the district court in granting the injunction.

The Allen Bradley case ${ }^{49}$ brought to the attention of the Supreme Court a com-

« Columbia River Packers Ass'n, Inc. v. Hinton, 315 U. S. 143 (1942). Further reference to this case is made infra.

${ }^{15} 38$ STAT. 730, I5 U.S.C. 512 (1940).

"Hinton v. Columbia River Packers Ass'n, r3I F. 2d 88 (C.C.A. 9th 1942).

${ }^{47}$ United States v. Borden Co., 308 U. S. 188 (1939).

${ }^{18}$ See note 44 supra.

40 Allen Bradley Co. v. Local Union No. 3, 325 U. S. 797 (1945). For the current stage in this litigation see Allen Bradley Co. v. Local No. 3, 164 F. 2d 7x (C.C.A. 2d 1947). See also United Brotherhood of Carpenters v. United States, 330 U. S. 395 (1947), where the question concerned the nature of the authorization by the union to make it liable for acts of union officials in a conspiracy to violate the Sherman Law. The Court did not find the authorizstion was proven. The point of this last case seems now to be covered by $\$ 2(13)$ of the Labor Management Relations Act of 1947. See also $\$ 301(b)$ and (a) and 93 Cong. REc. joor (1947). Pub. L. No. Ior, 8oth Cong., Ist Sess. (r947). A review of the major antitrust labor decisions may be found in Pierce, Labor and the AntiTrust Laws, 18 So. Carip. L. Rev. 'igr (1945).

This is not an article on labor unions and the antitrust laws, so no attempt is made to cite cven a selection. from the voluminous writings on this topic. Law review authors have attempted to find a pattern in the labor decisions and to isolate a formula expressing the position of the Supreme Court. The same thing has been happening for years in the commerce cases. Since the Justices of the Supreme Court doubtless read the reviews, and since several of them in the past have done the same sort of analysis and synthesis, it is by no means impossible that out of a multitude of decisions of particular cases often explained by inconsistent opinions writers will detect a controlling principle which will be accepted subsequently by the Court. Cf. United States v. Local 807, 315 U. S. 521 (1942). This case involved the Federal Anti-Racketeering Act of June I8, I934 (48 Stat. 979, 18 U.S.C. 5420 (1940)), and came to the Supreme Court on certiorari to review a judgment reversing a conviction of a union and members. While the Clayton Act ( $\$ 6$ and \$20) was mentioned in argument, it was not mentioned in the opinions. The Act provided a penalty for any person who with relation to interstate commerce obtains or attempts to obtain by use or threat of force payment of moncy, not including payment of wages by a bona fide employer to a bona fide employec. The defendants controlled New York City 
bination of contractors, manufacturers, and union which was designed, by the boycotting of recalcitrant local contractors and manufacturers and outside manufacturers, to gain market control of the electrical equipment business in the city of New York. The question before the Court, in the words of Mr. Justice Black, was, "Do labor unions violate the Sherman Act when, in order to further their own interests as wage earners, they aid and abet business men to do the precise things which that Act prohibits?"50 After reviewing the history of the Sherman and Clayton Acts, the labor legislation, and the leading Supreme Court decisions on these subjects, the learned Justice continued:

The result of all this is that we have two declared congressional policies which it is our responsibility to try to reconcile. The one seeks to preserve a competitive business economy; the other to preserve the rights of labor to organize to better its conditions through the agency of collective bargaining. We must determine here how far Congress intended activities under one of these policies to neutralize the results envisaged by the others.

It must be remembered that the exemptions granted the unions were special exceptions to a general legislative plan. ${ }^{61}$

The Court concluded that the union had violated the Sherman Act. The holding means that the same labor union activities may or may not be in violation of the Sherman Act, dependent upon whether the union acts alone or in combination with business groups. Mr. Justice Roberts, while agreeing with the conclusion, dissented from parts of the majority opinion. He pointed out that the purpose of the union was to exclude from use in the city of New York articles of commerce made outside the city and offered for sale to users within the city. It was completely to monopolize the manufacture and sale of all electrical equipment within New York and to exclude from use in the area every such article manufactured outside the city, whether in a closed union shop or not. Mr. Justice Roberts thought such conduct by the union was illegal even without a combination with business:

The course of decision in this court has now created a situation in which by concerted

trucking. They wanted to compel out-of-state trucks to pay a day's trucking wages whenever such trucks made direct deliveries to New York City assignees. This compulsion was exercised by defendants' lying in wait for trucks passing from New Jersey to New York, forcing their way into trucks and by beating or threats procuring from drivers or their employers the demanded payments. In some cases they assisted or offered to assist in unloading the trucks; in others they disappeared as soon as the money was paid. The Court, by Mr. Justice Byrnes (Chief Justice Stone dissenting), held that the Act was intended to suppress terroristic activities of professional gangsters, not to interfere with labor union activities. The exception in the Act was not limited to those who were employees prior to the payment. The test as applicable to this case was whether the objective of the defendants was to obtain the payment of wages, and not whether the intent of the truck owner was to pay for protection instead of service. The reversal of the conviction was affirmed.

In view of the subsequent history of federal labor legislation, leaders of the cooperative movement contemplating the limits of conduct under their several immunities may recall the quotation: "Caesar had his Brutus, Charles I his Cromwell, and George III . . . may profit by their example."

${ }^{80}$ Allen Bradley Co. v. Local Union No. 3, supra note 49 , at 801 .

"Id. at 806, 809 . 
action, unions may set up a wall around a municipality of millions of inhabitants against importations of any goods if the union is careful to make separate contracts with each employer, and if union and employers are able to convince the court that, while all employers have such agreements, each acted independently in making them .... notwithstanding the fact that the purpose and inevitable result is the stilling of competition in interstate trade and the creation of a monopoly. ${ }^{52}$

\section{Mr. Justice Murphy dissented, saying in part:}

The fact that the union has expressed its self-interest with the aid of others rather than solely by its own activities should not be decisive of statutory liability. What is legal if done alone should not become illegal if done with the assistance of others and with the same purpose in mind. ${ }^{63}$

Just as the Clayton Act and the Norris-LaGuardia Act constitute the charter of privileges and immunities of the labor unions, so the Clayton Act and the Capper-Volstead Act fulfill the same purpose in respect of agricultural cooperativesnot, as has been noted, for other cooperatives. Consumers' cooperatives and cooperatives of other enterprises must meet any condemnation by the federal antitrust laws with only the defenses available to any others engaged in collective business effort.

Section 6 of the Clayton Act says that nothing contained in the antitrust laws shall be construed to forbid the existence and operation of agricultural or horticultural organizations, instituted for the purpose of mutual help and not having capital stock or conducted for profit, or to forbid or restrain individual members from lawfully carrying out the legitimate objects thereof; nor shall such organizations or the members thereof, be held or construed to be illegal combinations or conspiracies in restraint of trade, under the antitrust laws.

Since the Clayton Act is not specific as to what are agricultural or horticultural associations, and since its immunity does not extend to cooperatives having capital shares, although a true cooperative may have capital shares and many of the older cooperatives were so organized, the Capper-Volstead Act ${ }^{54}$ was passed in Ig22 to clarify the cooperative exemptions. Cooperatives may be corporate or other forms of association with or without share capital. Producers include farmers, planters, ranchmen, dairymen, and nut and fruit growers. Associations may engage in processing, preparing for market, and handling and marketing products of members in interstate and foreign commerce. They may have marketing agencies in common. Several requirements are enumerated, including the one-man-onevote principle, limitation of dividends on share capital to 8 per cent, and no dealing in products of non-menbers to an amount greater in value than for members.

A significant omission is that there is no reference to purchasers' cooperative associations, agricultural or other, although most state cooperative statutes contain provisions permitting cooperative purchasing by associations of producers. While

${ }^{52} I d$. at 819 .

${ }^{\circ} \mathrm{Id}$. at 820 .

${ }^{84} 42$ STAT. 388 (1922), 7 U.S.C. $\$ \$ 291,292$ (1940). 
the latter type of association may conceivably come within the exemption of the Clayton Act, this possibility finds no confirmation in the Capper-Volstead Act.

The Capper-Volstead Act recognizes that cooperative associations might become monopolies and restrain trade. It provides that if the Secretary of Agriculture has reason to believe that any such association monopolizes or restrains trade in interstate or foreign commerce, he may act to protect the public. Apparently the Secretary is not to act unless he believes that the monopoly or restraint of trade unduly enhances prices. ${ }^{55}$ Does this mean that monopoly or common marketing agencies constituting combinations to fix prices are legal so long as the price is not too high? Such a result would be illegal for any other combination under the authority of the Trenton Potteries case, ${ }^{56}$ in which the Supreme Court specifically refused to consider the issue of fair price. Apparently the rule of the Trenton Potteries case does not apply to farm marketing associations.

If the Secretary of Agriculture believes that an association is unduly enhancing prices, he must serve a complaint with notice of hearing and conduct a hearing. If he finds the association guilty he may issue a cease-and-desist order. Nothing is said about the presentation of evidence by complainants against an association, although the rule-making power given to the Secretary could presumably permit the offering of testimony of outsiders, not voluntarily summoned by the Secretary. If an association disobeys the order of the Secretary, the Attorney General may institute proceedings in the federal district court to enforce the order. A decree of the court may be enforced by "injunction or other appropriate remedy." The section is apparently not a penal statute, since nothing is said about punishment for willful or other violation of the order of the Secretary. A violation of the court's decree would undoubtedly be a contempt and punishable as such.

The leading case on the Capper-Volstead Act is United States v. Borden Company, ${ }^{57}$ decided in 1939 . The case involved an indictment of five groups of defendants for violation of Section $I$ of the Sherman Act. One group included milk distributors, one was a cooperative association and its officers and agents, one was a union and its officials, one certain municipal officials of Chicago, and one consisted of certain individuals. The case came directly to the Supreme Court under the Criminal Appeals Act for construction of a statute after the district court had dismissed the indictment. It was contended that the acts complained of were those both formerly and subsequently legal by governmental approval under the Agricultural Marketing Agreement Act. ${ }^{58}$ On this point the Court thought the offenses charged were committed, if at all, during a period when the arrangements in question had not been licensed by the Secretary of Agriculture, and that the Act af-

\footnotetext{
85 The language of the statute is: "If the Secretary of Agriculture shall have reason to believe that any such association monopolizes or restrains trade in interstate or foreign commerce to such an extent that the price of any agricultural .product is unduly enhanced by reason thereof. . .."

${ }^{60}$ United States v. Trenton Potteries Co., 273 U. S. 392 (r927); accord, Socony Vacuum Oil Co. v. United States, 3 10 U. S. 150 (1940).

${ }^{67} 308$ U. S. 188 (1939), reversing 28 F. Supp. I77.

${ }^{88}$ Judicial Code $\$ 238,28$ U.S.C. $\$ 345,50$ STAT. 246 (I937), 7 U.S.C. $\$ 602$ (1940).
} 
forded no ground for construing the Sherman Act as inapplicable to three counts in the indictment. The Court then considered whether the agricultural cooperative defendant, the Pure Milk Association, was exempt by reason of the CapperVolstead Act. Chief Justice Hughes quoted at some length the lower court opinion, including the sentence:

The Capper-Volstead Act does not condemn any kind of monopoly or restraint of trade, or any price fixing unless such monopoly or price fixing unduly enhances the price of an agricultural product. The Act then, by section 2 thereof, commits to an officer of the executive department, the Secretary of Agriculture, the power of regulation and visitation. ... The court deduces from the Capper-Volstead Act that the Secretary of Agriculture has exclusive jurisdiction ... in the first instance. ... Until the Secretary of Agriculture acts, the judicial power cannot be invoked.50

It is not altogether clear how much of this argument was rejected when the Chief Justice observed, "We are unable to accept that view." What the Court decided was that the Capper-Volstead Act "cannot be deemed to authorize any combination or conspiracy with other persons in restraint of trade that these producers may see fit to devise." ${ }^{\text {" } 0}$ What was condemned was the combined attempt of all defendants, including distributors and their allies, to control the market. The Court did not hold, since the question was not presented, that the cooperative might not have fixed the price and the conditions of distribution, and compelled their acceptance by separate contracts with other parties concerned. ${ }^{61}$

On the subject of the exclusiveness of the jurisdiction of the Secretary of Agriculture, the Chief Justice said that Section 2 of the Capper-Volstead Act does not cover the entire field of the Sherman Law. He pointed out that the Sherman Act authorizes criminal prosecution and penalties, while the Capper-Volstead Act provides only for a civil remedy. The Capper-Volstead Act speaks only of monopolization, while the earlier law also concerns attempts to monopolize. Furthermore, the exemption statute says nothing about immunity in the absence of action by the Secretary. These observations by the Chief Justice leave some questions unanswered, since the Court in the Borden case was dealing with a conspiracy between producers and others. The Chief Justice seems to think that at least in the absence of action by the Secretary the penal provisions of the Sherman Act could still be invoked. It is at least arguable that the Capper-Volstead Act meant to free agricultural associations and their officers from criminal liability, although, as the Court has often said, repeal by implication is not favored. Suppose the Secretary of Agriculture should decline to act. Would that decision be conclusive on the Department of Justice, or even a decision by the Secretary that, since the price had not been

59 United States v. Borden Co., supra note 57, at 203, 204.

${ }^{10}$ Id. at 204-205.

${ }^{61}$ See United States v. Elm Spring Farm, 38 F. Supp. 508 (D. Mass. I94I), modified 127 F. $2 d 920$ (C.C.A. Ist 1942).

Cf. Parker v. Brown, 317 U. S. 338 (1942), where the California Agriculture Prorate Act for regulating marketing, including prices of California raisins, was held not within the intended scope, nor 2 violation, of the Sherman Law. The Court regarded this as a regulation of local concern in spite of the fact that most of the raisins were intended for interstate and foreign commerce. 
enhanced, he should not issue any cease-and-desist order? Finally, it seems odd that if a cooperative that had attained monopoly would be safe from prosecution so long as it did not enhance prices, it could.be prosecuted during the process of obtaining the monopoly. It must be remembered that the Chief Justice dissented from the opinion of the majority in United States v. Hutcheson, ${ }^{62}$ involving laborunion immunity under the Clayton Act and the Norris-LaGuardia Act. His dissent is in accord with his reasoning in the Borden case. It is submitted that the principle of deducing general legislative policy from several statutes, as announced by the Supreme Court in the Hutcheson case, would grant the cooperative a greater degree of immunity than suggested by the Chief Justice in the Borden case, although the actual decision is in accord with the later cases. ${ }^{63}$

If the congressional policy in limiting the application of the antitrust laws is to equalize the bargaining power of worker and employer and of farmer associations and industrial corporations, ${ }^{84}$ it may be relevant, in passing upon the reasonableness of restraints by cooperative associations, to consider exactly what is their relative bargaining power in any particular instance. While there has been considerable increase in the economic importance of cooperatives, their economic power can easily be exaggerated unless one considers both the still relatively small amount of buying and selling done by cooperatives and also the fact that frequently they

"s 312 U. S. $2 \times 9$ (I94I).

${ }^{62}$ See notes 44-46 supra, for cases under the fisheries' cooperative law. In United States v. Dairy Cooperative Ass'n, 49 F. Supp. 475 (D. Ore. 1943), the Department of Justice obtained an indictment against an agricultural cooperative association for violation of the federal antitrust laws. It was said by the court to be the first case brought by the Department against a farmers' cooperative, not acting in concert with others, in which the cooperative was charged with acts monopolistic in character. Judge McCulloch granted a motion of the defendant to find it not guilty. The court thought Congress by the Clayton Act had said that agricultural cooperatives were not to be punished, even though they became monopolistic. Judge McCulloch said, "I'am asked to scuttle the plain language of the Clayton Act as to cooperatives, as anti-labor courts scuttled the labor provisions of the same Act. . . ." Id. at 475. The opinion did not mention the Capper-Volstead Act.

Cf. Manaka v. Monterey Sardine Industries, 4 I F. Supp. 53 I (N. D. Calif. I94I). This case involved a cooperative association of boat-owners, similar to the one noted in the Columbic River Packers case, supra, note 44. While the Clayton Act gives no exemption to such cooperatives, they are authorized by the Act of June 25, I934, 48 STAT. 1214, 15 U.S.C. $\$ \$ 52$ I, 522 (1940). The statute is similar to the Capper-Volstead Act with the substitution of the Secretary of Commerce for the Secretary of Agriculture. The court said that the fact that the Secretary of Commerce had not acted does not indicate that an illegal combination may not exist. The court awarded triple damages for violation of the Sherman Law. The Association was not acting in concert with others. See, for a subsequent development not connected with the principal issue, The Ocean Gift, Manaka v. Monterey Sardine Industries, Inc. 48 F. Supp. 625 (N. D. Calif. 1942). Manaka was a resident Japanese alien.

What is perhaps the most important agricultural cooperative association antitrust case decided subsequent to the Clayton Act and prior to the Capper-Volstead Act is United States v. King, 229 Fed. 275 (D. Mass. 1915), 250 Fed. 908 (D. Mass. 1916). The defendant cooperative, the Aroostook Potato Shippers' Association, which controlled 75 per cent of all interstate potato shipments from Aroostools County, through a committee prepared a blacklist of undesirable receivers. Members were forbidden to deal with a blacklisted person. The list was also circulated to commission merchants and others, who were informed they would be blacklisted if they dealt in potatoes with those on the undesirable list. The defendant was indicted for conspiracy in restraint of trade. A demurrer to the indictment was overruled. The court said the secondary boycatt was not, under the Clayton Act, a legitimate means of carrying out the objects of the association.

ou See Comment, The Basis of Labor Exemptions from the Anti-trust Laws, 54 Yale L. J. 853 (1945). 
participate in only one phase of the distributive process. ${ }^{65}$ Although the cooperatives may come close to controlling parts of the marketing machinery for certain fruits and nuts in particular areas, their products are usually in competition with similar products from other areas as well as with even more significant competition from other products. Cooperatives may have a high degree of economic power in certain regions and at some point in the marketing process. Their present size, rate of growth, and, on the whole, their policies, give little cause to fear the assertion by them of any tyrannical economic power at any early time, if at all, on the national level, and that is the type of activity with which the federal antitrust laws are primarily concerned.

The foregoing considerations do not justify the conclusion that agricultural cooperatives could assert economic power combined with political power with impunity. Their immunity under the antitrust laws is by no means so explicit as that of labor organizations. Cooperative associations, even if technically nonprofit, are engaged in business. They compete with other business in a different way from that in which unions compete with employers. To be comparable, the unions would have to engage directly in productive enterprise of their own, for example in the making of phonograph records. The Clayton Act provision that labor is not a commodity may point to a further distinction between labor organizations and cooperatives. Furthermore, while it may be true that unduly restrictive decisions by the Supreme Court in labor cases induced Congress to grant almost unlimited power to labor unions, the effect on public opinion of uncontrolled labor-union conduct, and the consequent response by Congress with new labor legislation, suggests the query whether the Supreme Court's labor decisions on restraint of trade may not have reflected the underlying public sentiment as to the proper meaning and effect of antitrust legislation. The political history of the United States has already shown that both business and labor for a time, by adroit strategy and pressure, can gain special privilege. Both overreached themselves to an extent that aroused condemnation by a popular majority. Farm organizations may well be satisfied with the degree of favor they now enjoy with government, even assuming a somewhat conservative judicial attitude toward their antitrust immunities.

Recent decisions of the Supreme Court and other courts have given new importance to the idea of monopoly under Section 2 of the Sherman Act. ${ }^{86}$ Perhaps

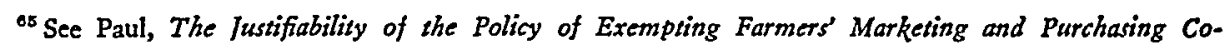
operative Organizations from Federal Income Taxes, 29 Mins. L. REv. 343, 356 et seq. (1945).

${ }^{\circ}$ See especially American Tobacco Co., Liggett \& Myers Tobacco Co., R. J. Reynolds Tobacco Co., et al. v. United States, 328 U. S. 781 (I946), and United States v. Aluminum Co., 148 F. 2 d 416 (C.C.A. 2d 1945). The latter case is a final decision on certificate from the Supreme Court because of a lack of a quorum. The certificate was issued under authority of Act of February 1, x903, as amended June 9, 1944, 32 Sткт. 843,58 StیT. 272, 15 U.S.C. $\$ 29$ (1940). The Aluminum case was tried before Circuit Judges Learned Hand, Augustus Hand and Swan. The opinion was by Learned Hand. See also Cahill, Recent Trends in the Antitrust Laws, I Record (Ass'n of the Bar of the City of New York) 201 (I946); Levi, The Antitrust Laws and Monopoly, 14 U. of CHI. L. REv. 153 (r947); Rostow, The New Sherman Act: A Positive Instrument of Progress, 14 U. of CH. L. Rev. 567 (1947); Note, Enforcement of Section 2 of the Sherman Act, 54 YAI. L. Y. 860 (1945). 
the conceptions of monopoly as held by the lawyer and the economist are coming closer together. ${ }^{67}$ For a long time we have been justified in assuming that mere size was not an offense under the Sherman Law. ${ }^{68}$ The emphasis in the decisions was on predatory practices and restraints regarded as unreasonable. Recent cases such as those involving the Aluminum Company and the three tobacco companies (American, Reynolds, and Liggett \& Myers) ${ }^{69}$ indicate that mere size, at least measured by national standards, in the future must be given much more attention. It is possible that this significant development may be extended to dominance of the market even where the market in question is only a small segment of the national economy, and the product involved, like aluminum, is in active competition with other products over which the alleged offender has no control. The space limits of this discussion do not permit a detailed analysis of recent developments in the general field of antitrust laws. It is perhaps enough to say that these developments should have the serious attention of those who make the policies of cooperative associations. With the exclusiveness of the enforcement procedure by the Secretary of Agriculture in doubt in cooperative cases, and with the added fact that in any cvent the Secretary could not successfully challenge the policy of an administration of which he is a part, any approach to complete control of even a single agricultural product might subject the dominant cooperative to attack under the antitrust laws. Such control could be permitted by Congress and, as has been indicated, it is arguable that it is already permitted by the aggregate of federal legislation favorable to cooperatives, subject only to the potential protection of the public by the Secretary of Agriculture against unfair prices. The public, however, as represented by the Government, might not agree with agricultural interests as to fairness of price. What if a single cooperative should have the same dominance over raisins that the Aluminum Company has over aluminum ingots? What if cooperative associations respectively controlling walnuts, pecans, and peanuts should create a single marketing agency? What if there should be a similar agency for California and Florida oranges, or for Florida, Texas, and California grapefruit? What if marketing control should concern itself, not so much with price as with division of domestic and foreign markets? From what I know of the cooperative leaders, I doubt if they will subject themselves to attack. Their present policies suggest no violation of the antitrust laws as presently interpreted. If their power should increaseand power is seductive, and it is easy to be deceived by self-interest-the cooperative agricultural associations may find their antitrust immunity something less than complete. The safe rule for the farmers' organizations is to obey the prin-

\footnotetext{
" Mason, Monopoly in Law and Economics, 47 Yale L. J. 34 (1937); I AMERICan Individual Enterprise System, c. X, Prices, 48I; II id., cc. XII, XIII, Competition and Monopoly, 589; Donovan, Economic Concentration and the Antitrust Laws, 29, 1947 Proc. Sec. Corp. Banking and Merc. L2w, A.B.A.

"See United States v. United States Steel Corporation, 25 I U. S. 4I7 (1920); United States จ. International Harvester Co., 274 U. S. 93 (1927).

${ }^{\circ 0}$ Supra note 66.
} 
ciples of the competitive system. Monopoly power as a condition of profit is largely a delusion in any event. It means stagnation instead of progress. Even if it could be attained as to any product, the rivalry of other products would make the victory an empty one. The consumer is still king in America, and any business program based on the assumption that the consumer is a fool will pay for its error in reduced profits. The future success of cooperative farm marketing depends upon adherence to the practices of aggressive competition for the favor of the ultimate consumer. ${ }^{70}$

${ }^{70}$ See Note, Business Regulation: Recent Application to Cooperative Organizations, 29 Corn. L. Q. 25 I (1943); AGriculturat CoOperattves in the Post-War Period (United States Department of Agriculture, 1945). 